$10 \mathrm{IKC}-340$

\title{
PETROLOGY OF P-5 AND P-13 KIMBERLITE FROM LATTAVARAM KIMBERLITE CLUSTER, WAJRAKARUR KIMBERLITE FIELD, ANDHRA PRADESH, INDIA
}

\author{
Gurmeet Kaur*, Korkoppa, M. * and Fareeduddin ${ }^{*}$ \\ ${ }^{*}$ CAS in Geology, Panjab University, Chandigarh-160014; "PPOD division, \\ Geological Survey of India, Bangalore*Email:gurmeet28374@yahoo.co.in
}

\section{INTRODUCTION}

The Dharwar craton of India (Fig. 1) is divided into Eastern Dharwar Craton (EDC) and Western Dharwar Craton (WDC) along crustal scale shear zone located along the eastern margin of the Chitradurga schist belt (Swami Nath et al., 1976; Drury et al., 1984; Chadwick et al., 2000). All the kimberlites and lamproites so far discovered in south India form part of EDC. The kimberlites occur in clusters in four identified fields, namely, 1. Wajrakarur Kimberlite Field (WKF), 2. Narayanpet Kimberlite Field (NKF), 3. Raichur Kimberlite Field (RKF), and 4. Tungabhadra Kimberlite Field (TKF). Most of the WKF pipes are diamondiferous. Besides the four kimberlite fields there are two lamproite fields, namely, 1. Krishna Lamproite Field (KLF) and 2. Nallamalai Lamproite Field (NLF) which also form part of EDC (Fig. 1; cf. Ravi et al., 2009).

\section{WAJRAKARUR KIMBERLITE FIELD}

The Wajrakarur Kimberlite field (120 km X $60 \mathrm{~km}$ ) lies in Anantpur district, Andhra Pradesh and host 30 kimberlite pipes distributed in five clusters, namely, Wajrakarur cluster (7 pipes), Lattavaram cluster (7 pipes), Chigicherla cluster (4 pipes), Kalyandurga cluster (6 pipes) and Timmasamudram cluster (6 pipes) (Reddy, 1987; Nayak and Kudari, 1999; Sravan Kumar, 2004; Mukherjee et al., 2007; Srinivas Choudary et al., 2007). The kimberlites of WKF are hosted by the granites and gneisses of the Eastern Dharwar Craton (Figs. 1, 2). The detailed account on the mode of occurrence and characteristics of the individual pipes of WKF are given by Neelkantam (2001). The kimberlite exposures are capped by 0.5 to $1.5 \mathrm{~m}$ thick calcrete. Kimberlites of WKF are of middle to late Proterozoic age ranging from 840 to $1153 \mathrm{Ma}$ (Paul et al., 1975; Anil Kumar et al., 1993, 2007; Chalapathi Rao et al., 1996).

Traditionally, all the potassic-ultramafic intrusions of this region were classified as kimberlites. Recent reclassification of a kimberlite Pipe-2 as lamproite (Mitchell, 2010) from the Wajrakarur Kimberlite Field necessitated re-look of the other kimberlite bodies in the region with a view to classify them as per mineralogic-genetic classification scheme (Mitchell, 1986). Thus two pipes P-5 and P-13 of Lattavaram cluster, in Wajrakarur Kimberlite Field were chosen for detailed mineralogical studies and the results are presented in this paper.

\section{GEOLOGY OF PIPE-5 AND PIPE-13:}

The pipe P-5 is situated at about $1 \mathrm{~km}$ east of village Muligiripalli (Fig. 2). Outcrops of medium to fine grained kimberlite with autoliths and crustal xenoliths occur under a less than a meter calcrete cover. This as an elongated body. The main crustal fragment is of pink granite that surrounds the pipe rock. The kimberlite outcrops are intricately associated with boulders of pink granite. The rock is melanocratic to hypermelanic, hard and compact (Fareeduddin, 2008). 


\section{$10^{\text {th }}$ International Kimberlite Conference, Bangalore - 2012}

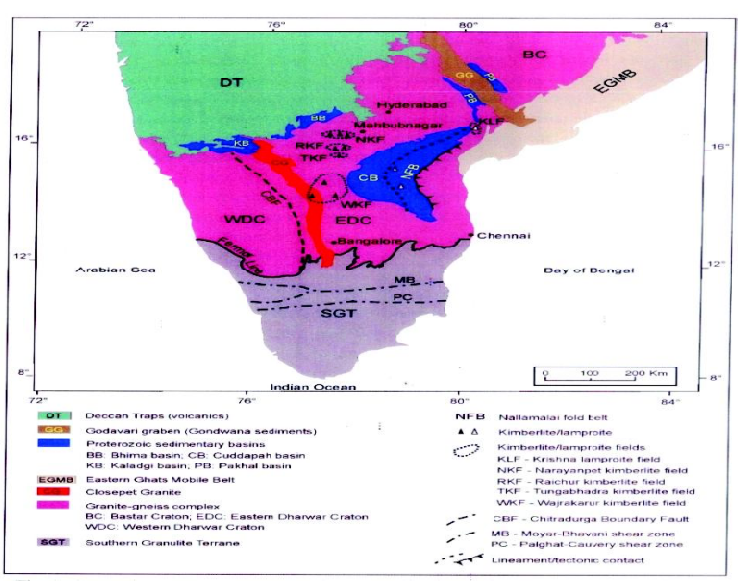

Figure 1. Generalised geological map of southern India showing kimberlite and lamproite fields in the Dharwar Craton (cf. Ravi et al., 2009).

Pipe P-13 referred to as Thummatapalle kimberlite occurs at about $1.4 \mathrm{~km} \mathrm{NE}$ of Thummatapalle village (Fig. 2). It is situated very close, $2.5 \mathrm{~km} \mathrm{SW}$ of the Muligirapalle pipe P-5. The oval shaped body is emplaced into the younger granitoids. A few melanocratic fresh outcrops of hardebank variety represent kimberlite body whereas the rest of the body is highly weathered and carbonated. In hand specimens olivine macrocrysts and megacrysts upto $5 \mathrm{~cm}$ size can be found. The phlogopite content is highest among all kimberlite samples of WKF (Fareeduddin, 2008).

\section{PETROLOGY OF PIPE-5 AND PIPE-13:}

The pipe $\mathrm{P}-5$ and $\mathrm{P}-13$ rock shows inequigranular texture with macrocrysts and microphenocrysts in a fine grained segregated groundmass. Xenoliths and xenocrysts are observed at places in both the pipes.

Both the kimberlites have olivines (fresh and serpentinised) as the characteristic major mineral. The prominent groundmass minerals in both constitute monticellite-kirschsteinite, spinel, perovskite, phlogopite, apatite, magnesian ilmenite, pyroxene along with serpentine, chlorite and carbonate.

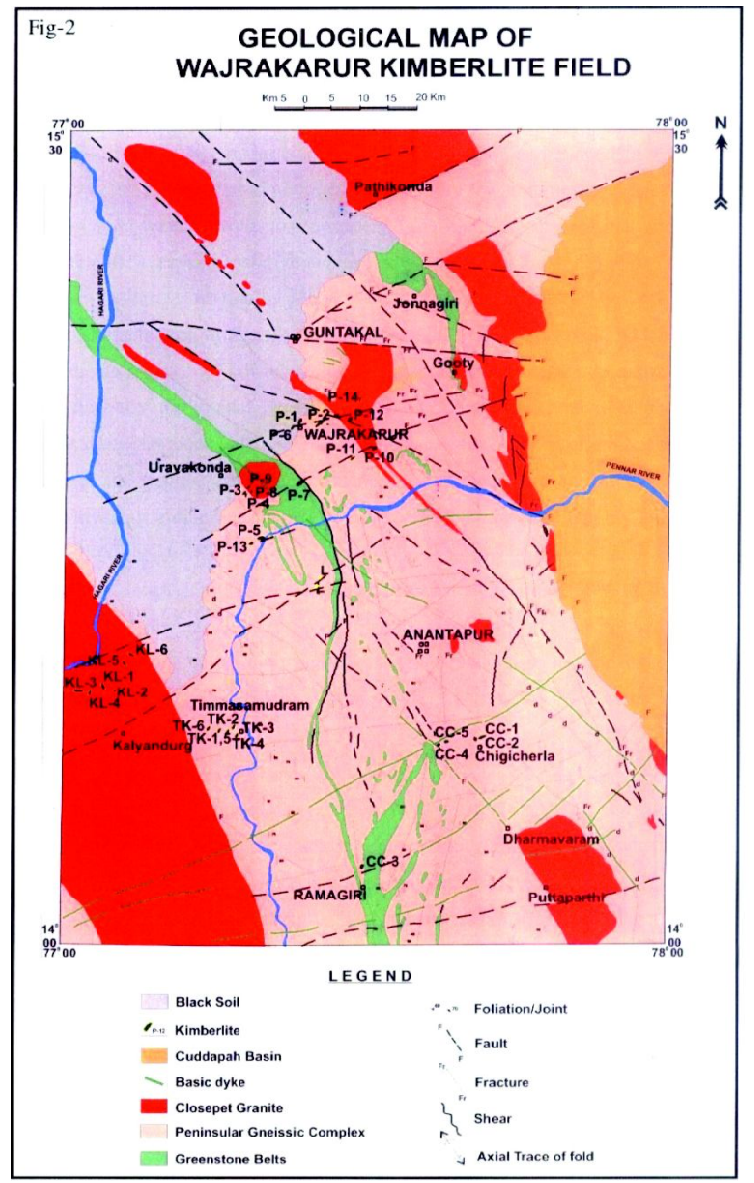

Figure 2. Geological map of Wajrakarur kimberlite field, Anantpur district, Andhra Pradesh (cf. Ravi et al., 2009).

The pipe P-5 and P-13 kimberlites exhibit macrocrystal textures and have two generations of olivine with variable contents of macrocrystic (upto 6mm) and micro-phenocrystic olivine. At places polycrystalline olivine grains are observed. The macrocrystic olivine is fresh compared to the groundmass and microphenocrystic olivines that are largely altered to serpentine.

The phlogopites from $\mathrm{P}-5$ are low in alumina $\left(\mathrm{Al}_{2} \mathrm{O}_{3}<\right.$ wt $\left.8 \%\right)$ also reported by Scott Smith, 1989 , compared to those from P-13 $\left(\mathrm{Al}_{2} \mathrm{O}_{3}<12\right.$ wt \%). Micas from both the pipes are barium poor $(\mathrm{BaO}<2$ wt \%). The titanium content is higher for P-13 phlogopites (up to $5 \mathrm{wt} \% \mathrm{TiO}_{2}$ ) compared to P-5. At places poikiolitic laths of phlogopite contain inclusions of perovskite and spinel. 


\section{0 $^{\text {th }}$ International Kimberlite Conference, Bangalore - 2012}

The P-5 has diopside laths occurring as clusters whereas the P-13 has minor amount of pyroxene and is almost devoid of these pyroxene clusters.

Both the pipes are characterized by the presence of macrocrystal $(0.1-0.5 \mathrm{~mm})$ and groundmass $(0.001-0.1 \mathrm{~mm})$ spinels. Both the pipes have atoll and necklace textured spinels. The atoll spinel in Fig. 3 has Ti-poor and chromium enriched core and Ti-rich and chromium poor rim (Table 1). Four varieties of spinels i.e. ulvospinel, magnesium ulvospinel, magnesium chrome spinel and magnetites are recorded in both the pipes. The ulvospinels, most dominant among spinels, from both the pipes are low in alumina $(<3 \mathrm{wt} \%)$, high in titanium (10-20 wt \%) and iron $(>60 \mathrm{wt} \%)$. The spinels exhibit compositional trends identical to those found in kimberlite magmatic trend $\mathrm{T} 2$. Intergrowth of spinel and perovskite is observed at number of places.

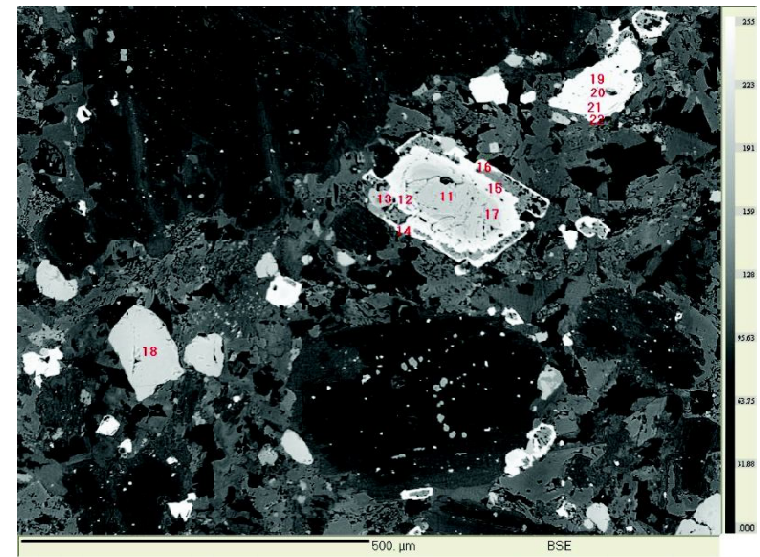

Figure 3. Atoll spinel in P-5. The composition at the points marked in the figure are given in Table 1.

Table1. Atoll spinel compositions at the points marked in the above figure.

\begin{tabular}{lrrrrrrr}
\hline $\mathrm{wt} \%$ & 11 & 12 & 13 & 14 & 15 & 16 & 17 \\
\hline $\mathbf{M g O}$ & 13.92 & 0.55 & 0.09 & 0.31 & 2.03 & 0.22 & 12.88 \\
$\mathbf{C a O}$ & 0 & 0.17 & 38.98 & 0.48 & 2.15 & 0.3 & 0.03 \\
$\mathbf{M n O}$ & 0.24 & 2.01 & 0.03 & 1.29 & 2.17 & 1.4 & 0.24 \\
$\mathbf{F e O}$ & 14.07 & 72.26 & 1.5 & 75.04 & 63.87 & 76.57 & 15.89 \\
$\mathbf{A l}_{2} \mathbf{O}_{3}$ & 18.44 & 1.35 & 0.14 & 0.37 & 1.93 & 0.65 & 17.85 \\
$\mathbf{C r}_{2} \mathbf{O}_{3}$ & 50.85 & 4.75 & 0.03 & 0.27 & 5.17 & 0.39 & 51.55 \\
$\mathbf{S i O}_{2}$ & 0.09 & 0.19 & 0.06 & 0.83 & 3.53 & 0.19 & 0.13 \\
TiO $_{2}$ & 0.1 & 12.62 & 56.13 & 12.03 & 14.56 & 12.99 & 0.15 \\
\hline Total & 97.79 & 93.97 & 97.03 & 90.72 & 95.51 & 92.78 & 98.79 \\
\hline
\end{tabular}

Euhedral to subhedral grains of perovskites with bimodal size distribution occur as discrete grains throughout the rock. Perovskites also occur in association with spinels. They often form necklace around altered olivine grains. They have in general low LREE contents $(<3 \mathrm{wt} \%)$, but in a few grain the LREE content goes upto $16 \mathrm{wt} \%$ $\left(\mathrm{Ce}_{2} \mathrm{O}_{3}-5-11\right.$ wt \%; $\mathrm{La}_{2} \mathrm{O}_{3}-2-6$ wt \%). P-5 perovskites have marginally higher content of LREE's compared to P-13 perovskites.

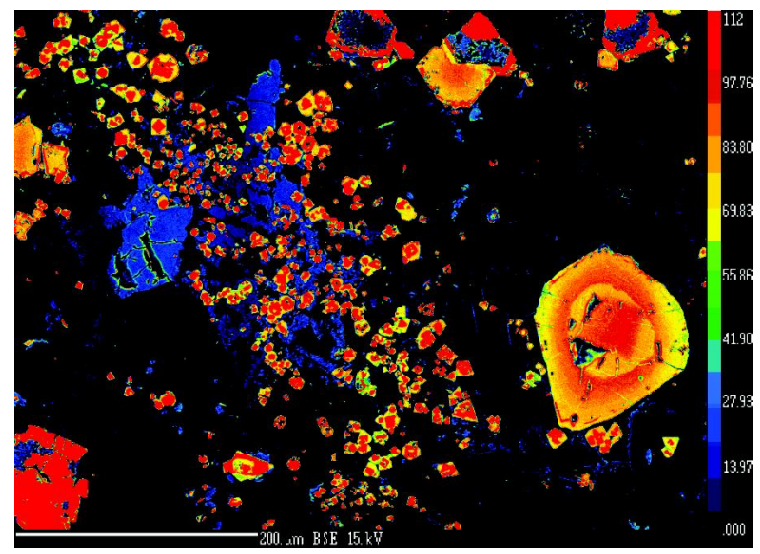

Figure 4. Bimodal size distribution of perovskites in pipe P-5. The very small grains are enriched in LREE's compared to the grain lying in the lower right corner.

Pipe P-13 has angular magnesian ilmenite grains varying in size from $0.2 \mathrm{~mm}$ to $1.5 \mathrm{~mm}$ often bordered by numerous small euhedral to subhedral grains of perovskite and ulvospinel. The $\mathrm{Mg}$ ilmenite grains show fine exsolution lamellae of chrome ulvospinel and ilmenite (Figs. 5 and 6, table 2). The composition of ilmenites is in the ilmenite-geikielite range. 4,6- host Mg-ilmenite

Table 2. Compositions of Mg-ilmenite and chrome-ulvospinel and ilmenite-ilmenite intergrowths in pipe $\mathrm{P}-13$

\begin{tabular}{lrrrrrrrrrr}
\hline $\mathrm{wt} \%$ & 3 & 4 & 5 & 6 & 15 & 19 & 20 & 21 & 22 & 31 \\
\hline $\mathrm{TiO}_{2}$ & 23.09 & 57.65 & 18.2 & 55.75 & 52.43 & 56.12 & 52.24 & 56.24 & 51.51 & 56.49 \\
$\mathbf{A l}_{2} \mathbf{O}_{3}$ & 1.45 & 0.01 & 0.42 & 0.02 & 0.14 & 0 & 0.27 & 0.05 & 0.1 & 0 \\
$\mathbf{M g O}$ & 10.8 & 14.15 & 1.59 & 13.62 & 12.44 & 14.24 & 13.75 & 14.21 & 12.45 & 13.85 \\
$\mathbf{M n O}$ & 0.8 & 0.77 & 2.45 & 0.71 & 0.49 & 0.58 & 0.57 & 0.53 & 0.54 & 0.57 \\
$\mathbf{F e O}$ & 36.58 & 25.27 & 60.04 & 27.81 & 29.58 & 26.23 & 27.25 & 26.45 & 29.7 & 26.78 \\
$\mathbf{C r}_{2} \mathbf{O}_{3}$ & 26.64 & 1.15 & 11.87 & 0.61 & 4.01 & 1.26 & 4.64 & 1.65 & 3.52 & 0.92 \\
\hline Total & 99.36 & 99 & 94.57 & 98.52 & 99.09 & 98.43 & 98.72 & 99.13 & 97.82 & 98.61 \\
\hline
\end{tabular}




\section{$10^{\text {th }}$ International Kimberlite Conference, Bangalore - 2012}

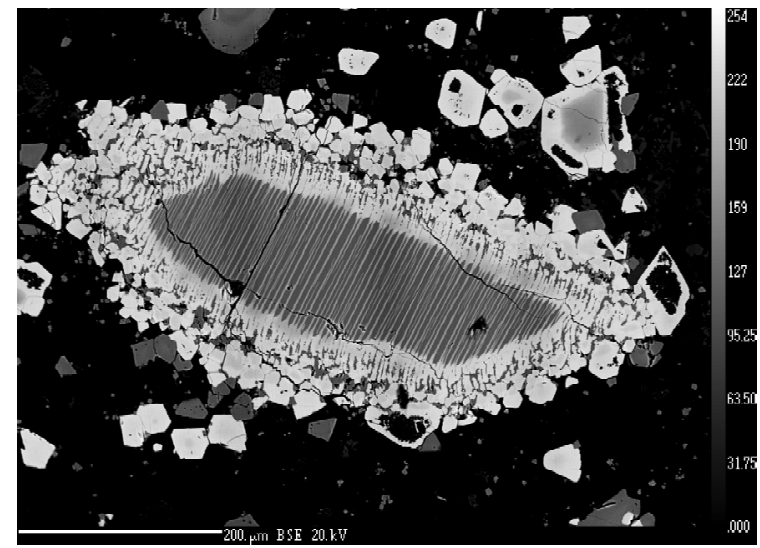

Figure 5. Mg-ilmenite megacryst with exsolved chromeulvospinel in $\mathrm{P}-13$. The grain boundaries of the $\mathrm{Mg}$ - ilmenitedecorated by ulvospinel and perovskite.

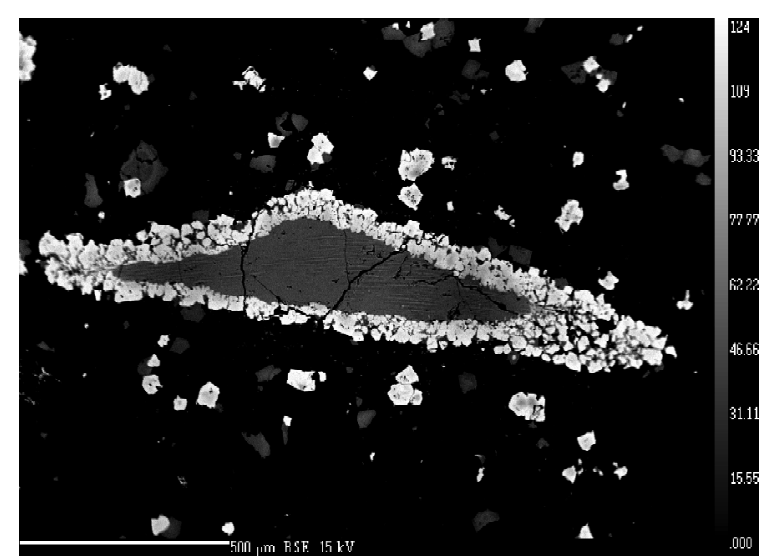

Figure 6. Megacryst of ilmenite with exsolved ilmenite rods in pipe $\mathrm{P}-13$. The megacryst margin is decorated with ulvospinels and perovskites.

and 3,5-exsolved chrome ulvospinel; 15,20,22host ilmenite and 19,21,31 exsolved ilmenite.

\section{CONCLUSIONS}

1. The mineralogical data suggests that both the kimberlites can be named as hypabyssal facies phlogopite kimberlites.

2. P-13 has more volume percent of macrocrysts, mg-ilmenite, phlogopite, spinels and perovskite compared to P-5.

3. The two pipes represent polyphase intrusions in close proximity within Lattavaram region where P-5 type bodies represent more evolved magmas compared to P-13 type kimberlitic intrusions.

\section{REFERENCES}

Anil Kumar, Heaman, 1. M. and Manikyamba, C. (2007). Mesoproterozoic kimberlites in south India: A possible link to $\sim 1.1 \mathrm{Ga}$ global magmatism. Precambrian Research, v. 154, pp. 192-204.

Anil Kumar, Padma Kumari, V. M., Dayal, A. M., Murthy, D. S. N. and Gopalan (1993). Rb-Sr ages for Proterozoic kimberlites of india: evidence for contemporaneous emplacement. Precambrian Research, v. 62, pp. 227-237.

Chadwick, B., Vasudev, V. N. and Hegde, G. V. (2000). The Dharwar craton, southern India, interpreted as the result of Late Archaean oblique convergence. Precambrian Research, v. 99, pp. 91-111.

Chalapathi Rao, N. V., Miller, J. A., Pyle, D. M. and Madhavan, V. (1996). New Proterozoic K-Ar ages for some kimberlites and lamproites from the Cuddapah basin and Dharwar craton, south India: evidence for non-contemporaneous emplacement. Precambrian Research, v. 79, pp. 363-369.

Drury, S. A., Harris, N. B. W., Holtz, R. W., ReevesSmith, G. J. and Wightman, R. T. (1984). Precambrian tectonics and crustal evolution in south India. Jounal of Geology, v. 92, pp. 3-20.

Fareeduddin, 2008. Training course on an introduction to the petrology of diamond bearing rocks and modern methods in exploration for, and evaluation of, primary diamond deposits. Geological society of India. 42pp.

Mitchell, R. H. (1986). Kimberlites: Mineralogy, Geochemistry and Petrology. Plenum press, New York and London, 442p.

Mitchell, R. H. (2010). Mineralogy of P2-West Kimberlite, Wajrakarur, A. P., India. Abstract Volume $6^{\text {th }}$ International Dyke Conference " Dyke swarm keys for geodynamic interpretation".

Mukherjee, A., Sravan Kumar, C., and Reddy, K. K. (2007). Two new kimberlites in Bommaganapalli area, Anantpur district, Andhra Pradesh, based on systematic stream sediment sampling and ground magnetic survey. Journal Geological Society of India, v. 69, pp. 625-640. 


\section{0 $^{\text {th }}$ International Kimberlite Conference, Bangalore - 2012}

Nayak, S. S. and Kudari, S. A. D. (1999). Discovery of diamond-bearing kimberlite in Kalyandurg area, Anantpur district, Andhra Pradesh. Current Science, v. 76, pp. 1077-1079.

Neelkantam,, S. 2001. Exploration for diamonds in southern India. Geol. Surv. Ind. Spl. Pub. No. 58, pp 521-555.

Paul, D. K., Rex, D. C. and Harris, P. G. (1975). Chemical characteristics and K-Ar ages of Indian Kimberlites Bulletin Geological Society of America, v. 86, pp. 364-366.

Ravi, S., Vaideswaran, T. and Rao, K. S. B. (2009). Field guide to Wajrakarur kimberlite field, Anantpur district, Andhra Pradesh, Geological Survey of India, 1-43p.

Reddy, T. A. K. (1987). Kimberlite and lamproitic rocks of Wajrakarur area, Andhra Pradesh. Journal Geological society of India, v. 61, pp. 131-146.

Scott Smith, B. H. (1989). Lamproites and kimberlites in India. Neues Jahrbuch Miner. Abh., v. 161, pp. 193-225.

Scott Smith, B. H., 1989. Lamproites and kimberlites in India. Neues Jahrb. Mineral. V 161, pp 193-225.

Sravan Kumar, C., Mukherjee, a. and Vishwakarma, R. K. (2004). Discovery of a new kimberlite pipe using multidisciplinary approach at kalyandurg, Anantpur district, andhara Pradesh. Geological society of india, v. 64, pp. 813-817.

Srinivas Choudary, V., Rau, T. K., Bhaskar Rao, K. S., Sridhar, M. and Sinha, K. K. (2007). Timmasamundram kimberlite cluster, Wajrakarur kimberlite Field, Anantapur district, Andhra Pradesh, Journal Geological society of India, v. 69, pp. 597-609.

Swami Nath, J., Ramakrishnan, M. and Viswanatha, M. N. (1976). Dharwar stratigraphic model and Karnataka cratonic evolution. Rec. geol. Surv. India, V. 107, pp. 149-175. 